\title{
VENOUS HYPERTENSION FOLLOWING AVERAGE ARTERIOUS-VENOUS FISTULA FOR HAEMODIALYSIS
}

\author{
Zdeněk Kojeckýa ${ }^{*}$, Petr Utíkal ${ }^{a}, Z^{2}$ deněk Sekanina ${ }^{a}$, Martin Köcher ${ }^{b}$, Eva Buriánkováb \\ ${ }^{a}$ First Surgical Department, Medical Faculty of Palacký University, Olomouc \\ ${ }^{b}$ Department of Radiology, Medical Faculty of Palacký University, Olomouc
}

Received: September 5, 2002

Key words: Central venous system / AV-fistula / Venous hypertension

The authors emphasize the need for the investigation of the central venous system prior to the insertion of an avfistula, this they consider to be of utmost importance in patients with anamnesis of central vessel access. After the av-fistula is inserted, an unrecognized obstacle (stenosis or thrombosis) may result in the occurrence of venous hypertension and hypofunction, this may lead to av-fistula malfunction.

\section{INTRODUCTION}

One complication following the insertion of a haemodialytic av-fistula is the occurrence of venous hypertension ${ }^{1}$. Its symptoms include oedema and loss of ability to move the limb, and necrotic changes in advanced stages (Fig. 1). The occurrence of venous hypertension poses a danger to the function of the av-fistula. Most commonly, it is caused by stenosis or an obstacle in the central venous system, which emerged after cannulation. The cannulation access which is most often affected by such complications is the v. subclavia. Prior to the av-fistula insertion, stenosis and thrombosis are mostly asymptomatic. After the av-fistula is inserted, the development of this complication is either early or late. Its occurrence is described in approx. $11 \%$ of all the cases.

\section{MATERIAL AND METHODS}

Between 1986 and 2000 the First Surgical Department of the Medical Hospital in Olomouc treated 690 patients with CHRI. A total of 830 primary and secondary av-fistulas was inserted- 610 of which were autologous and in 220 cases an ePTFE graft was used. 755 surgeries were performed due to the av-fistula failing to perform its function.

Cumulative patency rates of av-graft fistulas: $1^{\text {st }}$ year $-91 \%, 2^{\text {nd }}$ year $-84 \%, 3^{\text {rd }}$ year $-76 \%$, $4^{\text {th }}$ year $-70 \%, 5^{\text {th }}$ year $-61 \%$

Venous hypertension was manifested in $3.2 \%$ of all cases.
When inserting a primary av-fistula, we prefer autologous veins. The most common option is a modification of a radiocephalitic av-fistula according to Brescia and $\mathrm{Cimini}^{2}$. Another approach is the insertion in an elbow area, most often according to Gracz. When these options have been exhausted, we insert the ePTFE graft av-fistula (GORE company), which ow department has had extensive experience with $^{3}$. Before the av-fistula is created, we pay considerable attention to the pre-operative examination. At present, prior to the primary fistula creation we investigate the central venous system provided that the anamnesis and/or the clinical diagnosis shows a suspicion of the presence of an obstacle in this area. First, Doppler metric examination is carried out, which is, due to the increasing equipment accuracy, able to assess the axillary, subclavial and jugular veins rather well ${ }^{4,5}$. In case of uncertainty or demonstration of an obstacle, angiography and/or phlebography is carried out. The venous system is always examined by means of phlebography prior to ePTFE graft av-fistula creation. When inspecting the av-fistula, the examination is carried out according to the fistula type and the cause of the closure and we take into consideration the possibility of peroperational phlebography, often with PTA carried out. Patients with an ePTFE graft av-fistula are regularly examined by means of Doppler metrics ${ }^{6}$.

The therapy focuses on maintaining the primary cumulative function of the av-fistula as long as possible - i.e. on intervention before a thrombotic closure occurs. The methods of therapy include radiology, surgery or a combination of both. In the case of isolated stenosis, a simple PTA is most common; in some cases (immediate or early stenosis) a stent is implanted (Fig. 2 and 3). 


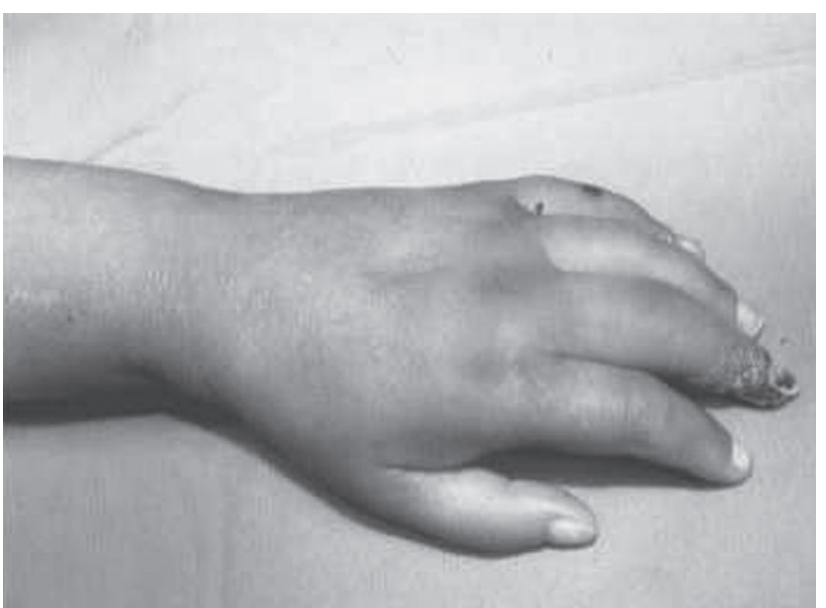

Fig. 1. Finger necrosis

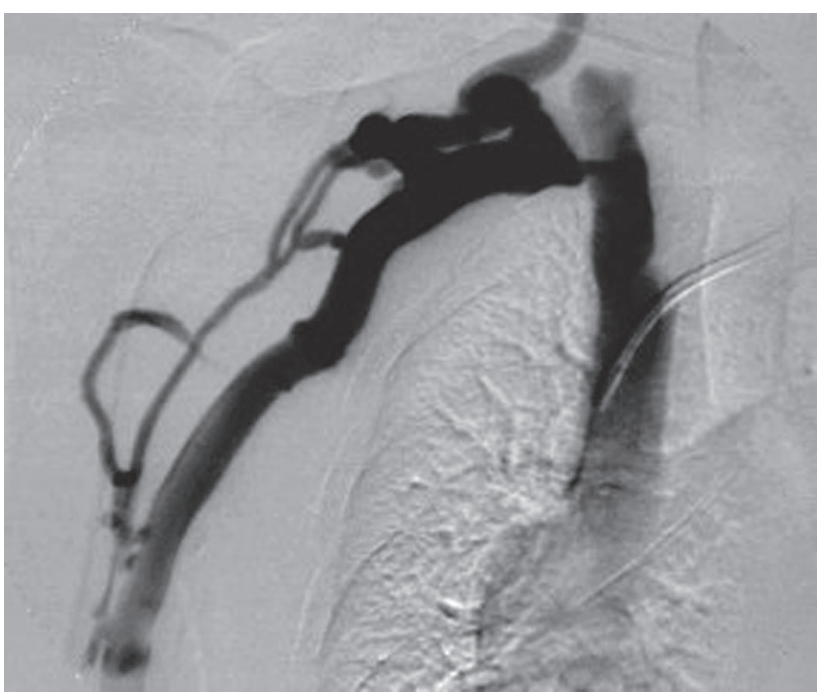

Fig. 2a. Stenosis of v. subclavia

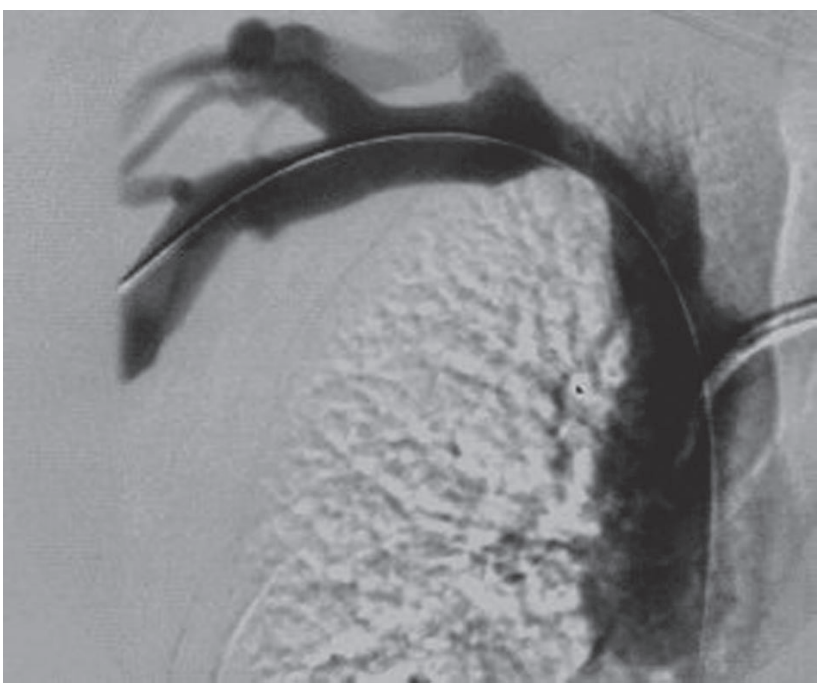

Fig. 2b. Condition after PTA

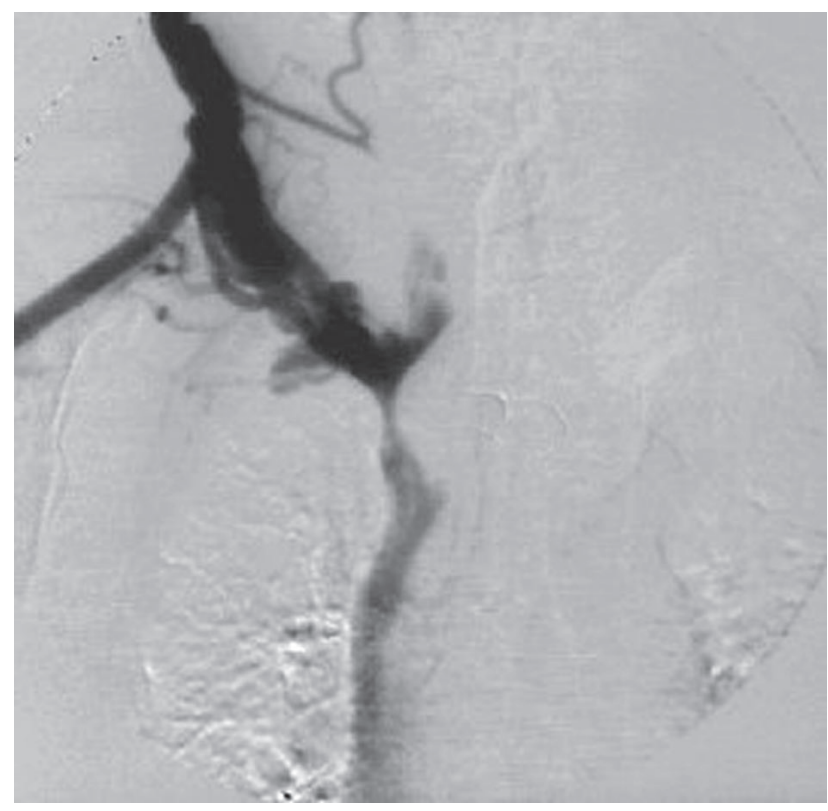

Fig. 3a. Stenosis of v. brachiocephalica

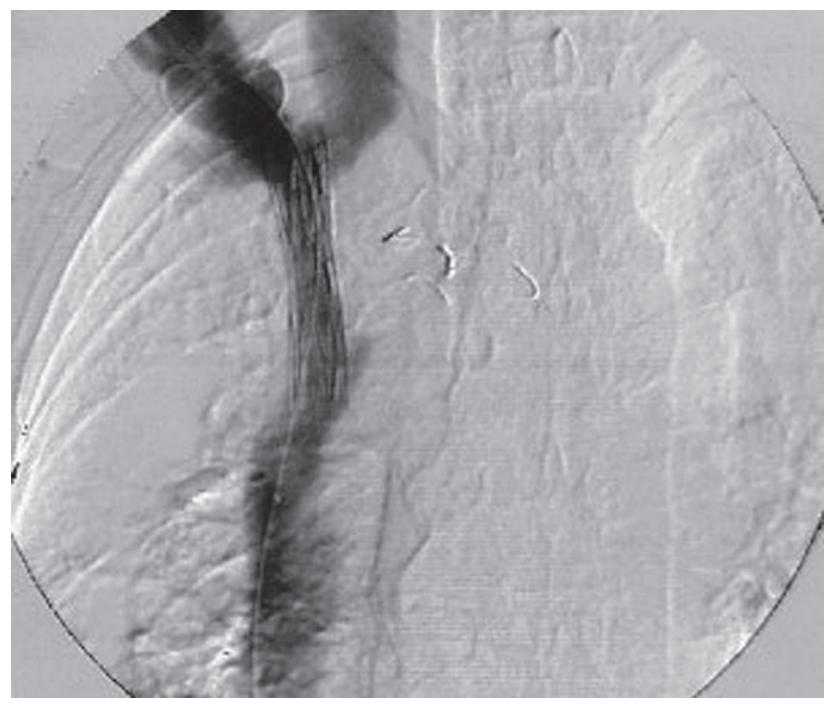

Fig. 3b. Condition after the stent implant

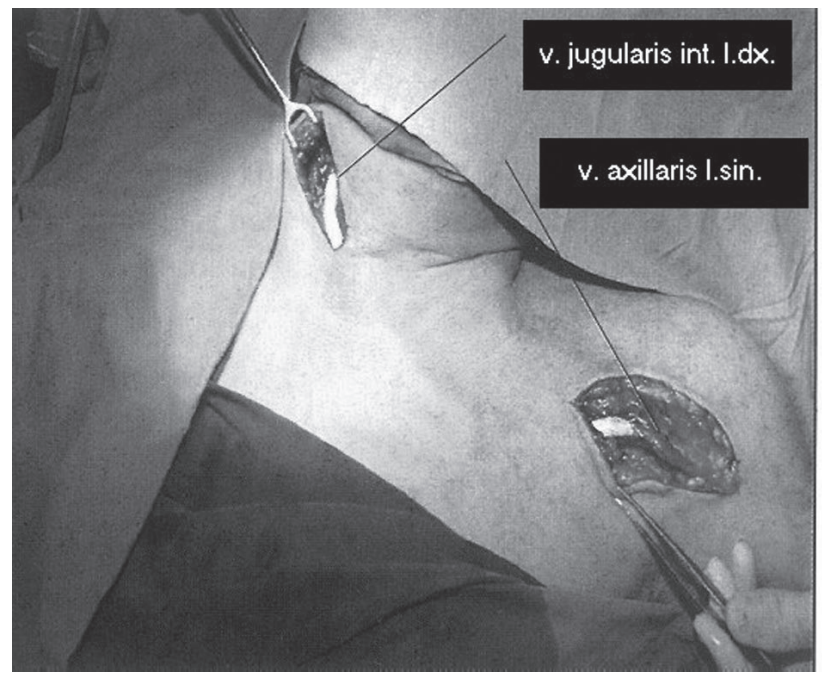

Fig. 4. Axillary-jugular contralateral bypass 
The surgical principle includes a bypass into a free discharge tract. Most often, the homolateral inner jugular vessel or contralateral axillary and jugular veins can be used (Fig. 4). If a closure of the superior vena or the brachiocephalitic vein is demonstrated, it is necessary to cancel the av-fistula by ligation. The prosthesis does not need to be extirpated, in this case.

\section{DISCUSSION}

The discharge tract - free central venous system plays an essential role in the function and use of the avfistula. The references give a $14-40 \%$ occurrence of patients with stenoses or thromboses in this zone before the av-fistula is inserted ${ }^{7}$. The most frequent cause of these changes is a previous central venous system access. Stenoses following the v.subclavia catheterization have been demonstrated in $42-50 \%$; in case of the v.jugularis interna they have been described in $0-10 \%$ of all cases ${ }^{8}$. Therefore, the recommended access is one by means of $\mathrm{v}$. jugularis interna.

Stenoses and thromboses do not develop in the central venous system under normal conditions, as the stenosed zone or the developed collateral circulation can handle normal venous circulation. During the increased blood flow after the av-fistula insertion (especially after the creation of an av-fistula by means of a prosthesis with a direct discharge into the brachial or axillary veins), these zones show signs of decompensation and symptoms of venous hypertension. This results in the hypofunction of the av-fistula, insufficient dialysis and closure of the fistula based on thrombosis during a blood circulation slowdown.

The treatment of such complications has to remove the manifestations of venous hypertension and at the same time maintain the function of the av-fistula. Reference studies show that this is achieved in approx. 50\% of all cases ${ }^{9,10}$. The basis of surgical treatment is a bypass into the free discharge tract. Typically, the homolateral or contralateral jugular vein is used for discharge. The contralateral subclavian artery is often affected and is rather unsuitable for further use ${ }^{11}$. If reconstruction is impossible and if there are accentuated manifestations of venous hypertension, ligation of the av-fistula and its creation in another place are indicated. Other methods of dealing with central stenoses include methods of intervention radiology - simple PTA (Percutaneous Transluminary Angioplasty) of relapsing stenosis with stent embedding ${ }^{12,13}$.

\section{CONCLUSION}

We consider the manifestation of central venous hypertension symptoms at our department to be rather low the cumulative function of av-fistulas being comparable to data provided by advanced international clinics. The treatment of venous hypertension is complicated and measures must be taken to prevent this complication from occurring. Based both on data provided by other studies and on our own previous experience, we recommend the central venous system access through $\mathrm{v}$. jugularis interna by means of a silicone catheter, a timely av-fistula creation with patients planned for haemodialysis and regular monitoring of av-fistula by means of ePTFE graft and treatment prior to its closure.

Provided the active search for clinically silent obstacles in the central venous access takes place, we anticipate long-term performance of the av-fistula created and a corresponding lower traumatism to patients involved in best chronic dialysis program. The cooperation of a surgeon, a radiologist and a nephrologist can provide the most suitable treatment of the patient.

\section{REFERENCES}

1. Bachleda P, Utíkal P (1996) Stenózy a trombózy centrálního žilního traktu jako příčina projevů venózní hypertenze po založení arteriovenózní spojky k hemodialýze. Rozl. Chir., 75, 492-495.

2. Brescia MJ, Cimino JE, Appel K, Hurwich BJ (1966) Chronic hemodialysis using venipuncture and a surgically created arteriovenous fistula. N Engl. J. Med., 275, 1089.

3. Bachleda P, Utíkal P (1996) Příspěvek k zakládání arteriovenózních spojek interpozicí ePTFE (GORETEX) protéz. Rozhl. Chir., 75, $26-30$.

4. Finlay DE, Longley DG (1993) Duplex and color Doppler sonography of hemodialysis aretriovenous fistula and grafts. Radiographics, 13, 983-989.

5. Older RA, Gizienski TA (1998) Hemodialysis access stenosis: early detection with color Doppler US. Radiology, 207, 161-164.

6. Schwab SJ, Raymond JR, Saeed M (1989) Prevention of hemodialysis fistula thrombosis. Early detection of venous stenosis. Kidney Int., 63, 707.

7. Surrat RS, Picus D (1991) The importance of preoperative evaluation of the subclavian vein in dialysis acces planning. Am. J. Roentgenol, 156, 623-625.

8. Schillinger F, Schillinger E, Montagnac R (1991) Post catheterization vein stenosis in haemodialysis: Comparative angiographic study of 50 subclavian and 50 jugular accesses. Nephrol. Dial. Transplant., 6, 722.

9. Currier CB Jr, Widder S (1986) Surgical management of subclavian and axillary vein thrombosis in patients with functioning arteriovenous fistula. Surgery, 100, 25-26.

10. Piotrowski JJ, Rutherford RB (1987) Proximal vein thrombosis secondary to hemodialysis catheterization complicated by arteriovenous fistula. J. Vasc. Surg., 5, 876-878.

11. Bachleda P, Utíkal P (2000) Použití vena jugularis interna jako výtokového traktu u arteriovenózních spojek k hemodialýze. Rozhl. Chir., 79, 439-441.

12. Glanz S, Gordon DH (1998) Axillary and subclavian vein stenosis: percutaneous angioplasty. Radiology, 168, 371-373.

13. Glanz S, Gordon DH (1985) Stenotic lesions in dialysis access fistulas: treatment by transluminal angioplasty using high - pressure balloons. Radiology, 156, 235-236. 